\title{
The Dolgellau Chalice and Paten
}

\author{
Allison Stielau
}

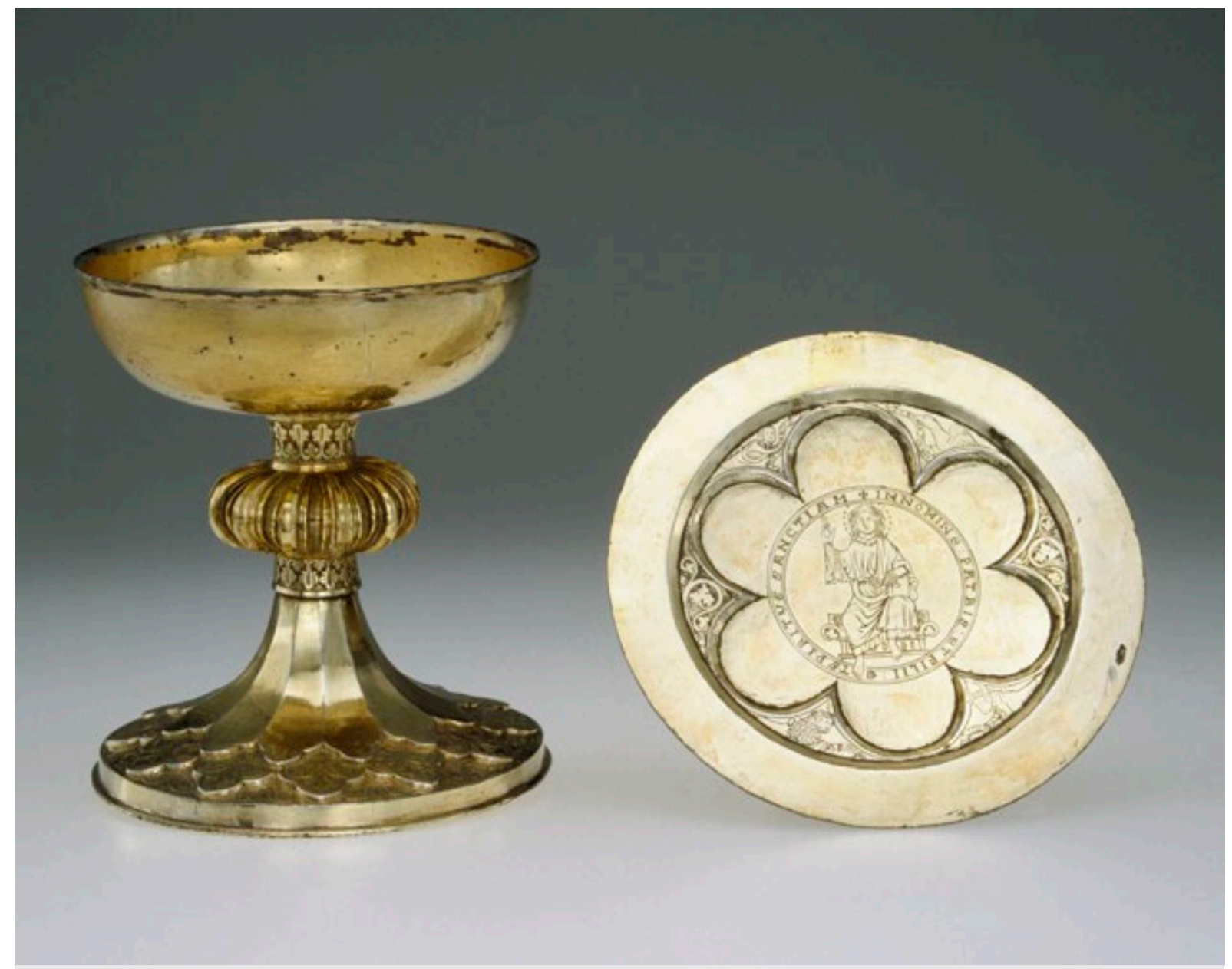

The Dolgellau Chalice and Paten, ca. 1230-1250

In 1890 two men working in the area around Dolgellau in North Wales discovered this pair of objects in a crevice between rocks. ${ }^{1}$ Encrusted with soil and plant matter, the objects were not at first identifiable. Removing the accumulated debris, however, revealed a gilt silver chalice and paten, vessels meant to hold the wine and bread during celebration of the Eucharist in Christian liturgy. Based on stylistic and iconographical evidence, experts dated the objects to the thirteenth century. The paten bears a six-lobed indent and engraved decoration of the Evangelists and of Christ enclosed in a circular band inscribed with the Trinitarian formula, "in the name of the Father, and of the Son, and of the Holy Spirit." The chalice has foliate decoration around its foot, a lobed and engraved knop, and shallow bowl, and is marked with the name of a possible donor or maker.

Here is a very rare survival of medieval sacred metalwork in the British Isles. Campaigns of liquidation during the Reformation sent most older church plate into the crucible. Few precious metal objects endured the rapacious confiscations of Henry VIII during 
the Dissolution of the Monasteries (1536-1541). Parish churches were allowed a single chalice and paten, but most of these were later converted to communion cups under pressure from Matthew Parker, Archbishop of Canterbury. Taking seriously the restoration of the cup to the laity in 1558 , which allowed all worshippers, rather than only priests, to fully participate in Communion, meant making a functional and aesthetic, as well as doctrinal, break with past ritual. Diocese by diocese, communities brought their chalices to local goldsmiths, who melted them down and made from their raw material simple standing cups. While these Elizabethan examples remain numerous, their predecessors are uncommon in the extreme. ${ }^{2}$

So how did this medieval chalice and paten come to rest in the soil of Merionethshire? They may simply have been stolen at some point and hidden by thieves unable to return to claim them. But thieves of church plate usually rushed to sell off their loot or convert it into bullion as quickly as possible. The fact that the Dolgellau finds remain intact suggests that they were hidden with an expectation of future recovery. A few anecdotes from the Dissolution record attempts by members of religious orders to physically hide precious metalwork from commissioners, rather than merely liquidating it in advance of collections, as many did. ${ }^{3}$ Cymer Abbey in nearby Llanelltyd may have been the original home of the chalice and paten and its Cistercian brothers those responsible for hoarding them away in a moment of crisis.

This small act of resistance is an important clue to the history of confessional change in Britain. Unlike on the Continent, where reform was driven by populist movements and political jockeying that varied intensely by region, English monarchs attempted to make the switch to a new faith swift, systematic, top-down, and universal. Their reforms gratified those already seeking a break from the customs of the late medieval church. But over the centuries material evidence has accrued indicating that some Christians did not give up their long-standing modes of worship so easily. In hopes that they might one day return again to pre-Reform piety, they buried sculptures and altars on church grounds, walled up crosses and relics, and converted functional objects to secular use to save them. ${ }^{4}$ The Dolgellau finds may have been hidden in response to the threat of seizure or destruction, evidence that some may have wanted to retain the old forms, if not simply the old treasure, of the church. The organized conversion of chalices to communion cups under Elizabeth-a literal re-formation-confirms that the vessel's shape signified a confessional stance.

The formal properties were, to put it another way, symbolically dense; they had strong cultural meaning for their users and beholders. The vessel's material, on the other hand, was highly alienable, susceptible to being sold, pawned, or converted into currency because of its monetary value. Anthropologists use the spectrum between these endpoints, "symbolically dense" and "alienable," to describe peoples' attitudes and actions toward possessions. ${ }^{.}$The more symbolically dense an object is, the more culturally and personally valued, the more resistant it becomes to alienation. An object's position on the spectrum can change with context, of course, and the Reformation is a prime case in which religious possessions like relics and cult statues long considered to be "inalienable" quite rapidly lost their sacred value for many. 
For the person or persons who hid the Dolgellau plate, though, these objects were likely still worthy of protection. The chalice and paten made the central rite of the Mass physically possible and materially sanctified and connected daily ritual to a long tradition of worship. Vivid testaments both to the moment of their making in the thirteenth century and to the moment of their rescue and hiding in the sixteenth, the Dolgellau finds of 1890 thus map two critical points in the material history of Christianity in Britain, from the peak of monastic life in the Middle Ages to its virtual demolition three centuries later.

(C) Allison Stielau

\section{Citation Guide}

1. Allison Stielau, "The Dolgellau Chalice and Paten," Object Narrative, in Conversations: An Online Journal of the Center for the Study of Material and Visual Cultures of Religion (2014), doi:10.22332/con.obj.2014.21

Stielau, Allison. "The Dolgellau Chalice and Paten." Object Narrative. In Conversations: An Online Journal of the Center for the Study of Material and Visual Cultures of Religion (2014). doi:10.22332/con.obj.2014.21

\section{Notes}

1. For a recent catalogue entry on the set, see Timothy Schroder, Renaissance Silver from the Schroder Collection (London: The Wallace Collection, 2007), 46-49.

2. Charles Oman gives a comprehensive account of these events in English Church Plate, 597-1830 (London: Oxford University Press, 1957), 129-144.

3. Though Oman argues that monks would likely have regarded a resurgence of their orders in England pessimistically, English Church Plate, 116, 117.

4. Sarah Tarlow, "Reformation and Transformation: What Happened to Catholic Things in a Protestant World?," in The Archaeology of Reformation, 1480-158o, eds. David R. M. Gaimster and Roberta Gilchrist (Leeds: Maney, 2003).

5. See discussions in Annette B. Weiner, "Inalienable Wealth," American Ethnologist 12, no. 2 (1985): 210-227. doi:10.1525/ae.1985.12.2.02a00020 and "Cultural Difference and the Density of Objects,” American Ethnologist 21, no. 2 (1994): 291-403. doi:10.1525/ ae.1994.21.2.02a00090

\section{Yale}

Copyright 2016 Yale University All rights reserved. 